\title{
From the Department of Child Health, Medical School, University of Indonesia, Jakarta
}

\section{Trends of Paediatric Nutrition in Developing Countries}

\section{by}

\section{R. SUTEDJO}

An infant born and reared in an adequate environment will obtain growth and development adequately and develop his genetic potentials to become an adult member of his community optimally in quality.

Such is in average the case in developed countries.

In developing countries, however, probably infants of only 10 to $20 \%$ of the population could be categorized as such.

A questionnaire among doctors in Indonesia revealed that the infant and pre-school mortality rates among their children are as low as in advanced countries, respectively 15.9 per thousand and 73.5 per ten thousand (Sutedjo et al., 1969).

This means that living in areas with so called tropical diseases is not a hindrance in obtaining low mortality rates, provided that conditions of $1 \mathrm{i}$ ving are similar to those of the Indonesian doctors.

What are those conditions?

Primarily a certain socio-economic level enabling the parents to provide their children with the necessary requirements, secondly availability of those requirements, thirdly a favourable hygienic environment and lastly knowledge of basic principles of sanitation and nutrition.

I put knowledge intentionally as the last item. The fact that in developed countries presently overnutrition exists is evidence that the man in the street in those countries does not exactly know what nutrition is.

On the other hand, protein calorie malnutrition does hardly occur in villages along the southern coast of West Java, although the inhabitants

Presented at the First Asian Congress of Paediatrics, Manila, Philippines 30 April 5 May, 1974.

Received 31st. Dec. 1973. 
of those villages are lacking in knowledge of nutrition.

The simple reason is that they catch tuna fish which is abundantly available in the ocean and give it to their children from the age of 6 months (Lauw Tj̈in Giok et al., 1965).

This is evidence that availability of adequate food within the means of the majority of the population in developing countries might be of more importance than providing them with knowledge by means of very expensive and time consuming programmes.

In talking about paediatric nutrition it becomes recently obvious that the most important periods in paediatric life are the last trimester of pregnancy and the first 6 months of life (Winick, 1969). This is in connection with the brain development with regard to the number of cells as well as the size, in particular with regard to the intensity of cell division. Any abnormality or disorder in that period' will have irreversible effect in later life.

One of the factors in those periods of life is undoubtediy the nutrients, in particular complete proteins, needed for the brain development.

Before we continue let us put forward the conditions surrounding childhood life in developing countries.
There are 5 major diseases as is obvious from a survey done in Jakarta on approximately 118.000 children visiting the outpatient department of the general hospital in the year 1968.

The first in frequency are upper respiratory tract infections, the second are gastro-intestinal tract disorders, the third protein calorie malnutrition, the fourth vitamin A deficiency and the fifth tuberculosis (Sutedjo et al., 1969).

Fitting in with the topic of this paper I would like to stress on the gastro-intestinal disorders. Infants and children frequently suffering from these dilsorders as it is the case in developing countries, have evidently damaged epithelial cells of the gut incapable to absorb food and/or to produce enzymes necessary for the digestion of food. The situation might be worse if the child is also suffering from protein calorie malnutrition.

What is then the most proper lood for infants?

Everybody will agree that the answer is breastmilk.

This is still applicable even for the infants of the above mentioned 10 to $20 \%$ elite group.

However, the fact is that nowadays economically less favourable mother in bigger as well as in smaller towns start to give artificial milk formula to 
their infants. Many reasons have been put forward to explain this unlucky phenomenon. One thing is for sure, i.e. the intensive propaganda of milk factories associated with incen tives to medical as well as paramedical personnel and the mothers themselves make the situation worse.

The question arises what kind of formula should be the best for infants in developing countries if the above mentioned situation is unavoidable.

Formulas fit for infants in developed counitries might be useful for infants of only 10 to $20 \%$ of the population belonging to the elite group.

As a consequence of the frequently occurring gastrointestinal disorders lactose intolerance is also expected to be high in frequency.

Figures obtained in Jakarta and elsewhere in Indonesia are of the order of 27.5 to $73.5 \%$ with an average of $56.6 \%$ for the age group of 0 to 36 months (Sunoto et al., 1971; Faried Bakry et al., 1973).

It becomes obvious that a low lactose formula is preferable.

Why lactose low and not lactose free formula?

Lactose free formula is certainly most proper for therapeutic purposes, but the absolute absence of lactose in the milk might cause an irreversible incapability of the epithelial cells of the gut to produce lactose which again might cause complaints if the child at an older age takes lactose containing delicacies like ice cream, cake etc.

Low lactose content of $1.0-1.4 \%$ is considered sufficient in curing as well as preventing diarrhoea due to lactose intolerance.

It is assumed that in recurrent diarrhoea absorption of milk fat may be impaired. Milk fat consists of $54 \%$ long chain saturated fatty acids and only $6 \%$ of medium chain triglycerides (MCT; 6-12 C atoms).

It is only recently established that the mechanism of absorption of long chain triglycerides (LCT; more than $12 \mathrm{C}$ atoms) needs a long process.

We all know that bile and pancreatic lipase are necessary to break down the LCTs into micelles which after absorption in the cell are transformed into chylomicrons. These chylomicrons should be transported through the lymphatics to reach the bloodstream and finally the liver.

The MCTs on the contrary, are directly absorbed into the epithelial cells from the lumen and will also come directly in the bloodstream (Gracey, 1972).

So, if possible, milk fat should be substituted by MCTs containing fat, because this may be more appropriate for developing countries.

Coconut oil which is easily and cheaply available in tropical countries consists of $63 \%$ MCTs. The disadvantage is that it contains only $1 \%$ linoleic acid which is considered as an 
essential unsaturated fatty acid necessary for the growth of the infant. This handicap is easily overcome by supplementation with a small amount of peanut oil which contains $26 \%$ linoleic acid or better with corn oil which contains $57 \%$ linoleic acid.

Both kinds of oils are easily available in tropical countries.

The next point is the proteins which in terms of absorrtion as aminoacids most probably give the least difficulty.

The question is again what quality and quantity of protein?

Although plant protein - in particular soybean - and fish protein could be used as substitutes, the global need for general use of these substitutes is not yet felt at this momenit.

Cow's milk protein remains the most guitable as substitute of breast milk protein.

In recent years the use of the so called humanized milk formula becomes more and more popular. What is humanized milk exactly? Methods of sterilization and homogenization in the process are improved. The most important change is that the protein content is lowered to the level of breast milk ( $\pm 1.8 \%$ ), whereas the lactalbumin - casein ratio is also made similar to that in breastmilk, i.e., approximately 1 to 1 .

The process in obtaining this latter is certainly complicated and makes the product expensive, not within the means of the poor masses of the po- pulation. It is indeed undemiable that formulas with "low protein" in the range of $1.6-1.8 \%$ are adequate enough to promote infant growth and development.

However, next to that humanized milk, formulas with high protein content in the range of $3.2-3.6 \%$ are still being produced by the same factory, distributed in the market and consumed by the infants without any adverse effect.

The question is now what should be the most suitable formula in terms of protein content for the infants of the poor masses of the population?

In this context one should take their financial capabilities into consideration. It is not a rare event that poor mothers do not follow the instructions given by the doctor in preparing the bottle for the infant.

They will likely overdilute the solution in order to save money. In case of minimal protein content of the formula the infant certainly will fail to thrive.

The middle course is probably the best; a protein contenit of $2.2-2.4 \%$ might be appropriate. It is now assumed that higher protein content not exceeding $4 \mathrm{gm}$ per $\mathrm{kg}$ bodyweight per day is not harmful to the infant.

Summarizing, a low lactose, MCTs containing formula with proteins of not too low level might be a safe solution for infants of the masses of developing countries. 
Vitamins and minerals should be adequately added. In particular for countries where goiter is still a problem a small amount of iodine should not be omitted.

A formula as stipulated above is being produced in Central Java.

Preliminary reports on trials simultaneously carried out in 3 universities gave promising results.

Leaving the period of infancy and coming to the preschool age as well as older age groups, the problem will remain the same and in terms of morbidity will become even worse. Highest frequencies in morbidity due to the $\mathbf{5}$ major diseases mentioned earlier occur in the preschool age period.

Lactose intolerance remains high also (Suharjono et al., 1971).

If milk drinking is a habit after the age of 1 year the above mentioned milk formula might still be feasable as supplementation.

However, after infancy children are adjusted to the family menu. In this case, if funds are available, the parents certainly will give their children the foodstuffs, which they themselves consider as delicacies i.e., meat, fish, egg, legumes etc.

In discussing nutritional problems one should separate the urban from the rural areas.

In urban areas home economics are the primary concern.

One could give advice about the food to be consumed, but if people can not afford to buy, advisory institutes might be of no great value,

In rural areas however, the situation is quite different.

In those areas where the food producing population live, the masses themselves are chronically in a state of shortage of adequate food.

The objective is then to promote and assist intensification of production and proper transportation throughout the whole country. The procedure is a multicomplex process and every section of the government should be involved in a joint intensive programme.

The ministry of health of the Indonesian republic has issued 5 booklets in which policies of the so-called Applied Nutrition Programme (ANP) are discussed in details (Direktorat Gizi, Departemen Kesehatan Republik Indonesia, 1972 - 1973).

ANP has as objectives the improvement of the nutrition of the family as a unit in the village. The objectives are motivation to and improvement of home gardening, school gardening, poultry, fishery and also education of the village families in basic knowledge of nutrition.

It would take a long time to discuss ANP on this occasion.

It is also for sure that the realization of ANP will take decades, will require skilled manpower, materials and high expenses before visible results could be obtained (De Wijn, 1972). 
Then arises the question whether setting up food industries and distribution of hygienically processed and packed foods might be less expensive and time consuming to reach the same objectives.

Another aspect of equal importance is that there exists an immense interrelationship between infections and host nutrition (Muslim A. Nathin, 1973).

Success will possibly be less if eradication of infections and improvement of sanitary environment are not simultaneously and jointly carried out with improvement of nutrition.

Last but not least, control of population explosion must be rigidly carried out.

\section{REFERENCES}

1. DE WIJN, DR. F.J.: Assignment report on the applied nutrition programme, Indonesia. WHO, Regional office for South-East Asia. SEA/NUT/39 Rev. 1. 20 Nov., 1972.

2. DIREKTORAT GIZI, DEPARTEMEN KESEHATAN R.I. JAKARTA: Konperensi Kerja Usaha Perbaikan Gizi Keluarga, no. 1 sampai 5 (workshop on Applied Nutrition Programme nos. 1 - 5, Ministry of Health, Republic of Indonesia, 1972 - 1973.

3. FARIED BAKRY, SUHARJONO, SUNOTO and HENTYANTO HENDARDJI: The severity of lactose intolerance in Indonesian children. Paediatr. Indones. 13 : 185 (1973).

4. GRACEY, M. and BURKE, V.: Medium chain triglycerides in malabsorption states in infants and children. Present concepts $5: 191$ (1972).

5. LAUW TJIN GIOK, I. TARWOTJO, DJOKOSAPTONO and HERMANA : A Nutrition study of preschool children of the Fishermen families at Pelabuanratu, West Java. Paediatr. Indones. 5 : 556 (1965).
6. MUSLIM A. NATHIN: Interrelationships between host nutrition and parasitic infection (literature review). Paediatr. Indones. 13 : 169 (1973).

7. SUHARJONO, SUNOTO, ASWITHA BUDIARSO and SUTEDJO: Lactose malabsorption in healthy Indoneslen preschool children. Paediatr. Indones. 11 : 251 (1971).

8. SUNOTO, SUHARJONO, J. MANGIWA and SUTEDJO: Lactose intolerance in chronic diarrhoea among Indonesian children. Paediatr. Indones. 11 : 1 (1971), special issue.

9. SUTEDJO, MOH. SUGIONO, ROHTIATMO, K., and SUDIJANTO : Morbidity in outpatients attending the Department of Child Health Medical school University of Indonesia. Paediatr. Indones. 8 : 235 (1968).

10. SUTEDJO, MOHAMAD SUGIONO, $\mathbf{s}$. MUSLICHAN and SUDIJANTO: Mortality in infants and children of Indonesian doctors. Paediatr. Indones. 9 : 1 (1969).

11. WINICK, M.: Malnutrition and brain development. J. Pediatr., 74:667 (1969). 